\title{
Perbedaan model pembelajaran kooperatif tipe jigsaw dan NHT untuk peningkatan karakter dalam pembelajaran IPS
}

\author{
Rijeki Sugestiningsih ${ }^{\mathrm{a}, 1^{*}, \text { Ajat Sudrajat }}{ }^{\text {b, } 2}$ \\ ${ }^{a, b}$ Program Pascasarjana, Universitas Negeri Yogyakarta, Yogyakarta, Indonesia \\ ${ }^{1}$ rijekisugestiningsih@gmail.com*,2ajat@uny.ac.id \\ *korespondensi penulis
}

\begin{tabular}{ll}
\hline Informasi artikel & ABSTRAK \\
\hline Kata kunci: & Penelitian ini bertujuan mengungkapkan perbedaan model pembelajaran kooperatif tipe \\
Jigsaw & Jigsaw dan NHT untuk: (1) peningkatan kerja sama, dan (2) peningkatan tanggung jawab \\
NHT & siswa dalam pembelajaran IPS. Penelitian ini merupakan eksperimen semu dengan pre- \\
Karakter & test post-test nonequivalent group design. Pengujian hipotesis dengan teknik \\
IPS & independent sample t-test. Hasil penelitian sebagai berikut. (1) Terdapat perbedaan \\
& model pembelajaran kooperatif tipe Jigsaw dan NHT untuk peningkatan kerja sama \\
& siswa dalam pembelajaran IPS, dengan nilai t $=0,004<0,05$. Rerata gain score kerja \\
& sama siswa menggunakan model kooperatif tipe Jigsaw lebih tinggi dibandingkan \\
& dengan NHT $(0,73>0,62)$. (2) Terdapat perbedaan model kooperatif tipe Jigsaw dan \\
& NHT untuk peningkatan tanggung jawab siswa dalam pembelajaran IPS, dengan nilai t \\
& $=0,000<0,05$. Hasil rerata gain score tanggung jawab siswa menggunakan model \\
& kooperatif tipe Jigsaw lebih tinggi dibandingkan dengan NHT $(0,87>0,57)$ Jadi, model \\
& pembelajaran kooperatif tipe Jigsaw lebih efektif untuk meningkatkan kerja sama dan \\
& tanggung jawab siswa.
\end{tabular}

Keywords:

Jigsaw

NHT

Character

Social studies

\section{ABSTRACT}

This research study aims to reveal the different the Jigsaw type cooperative learning model and NHT model on: (1) the improvement of students' teamwork, and (2) the improvement of students' responsibility in Social Studies teaching. The research was quasi experimental with the pre-test post-test nonequivalent group design. The hypotheses were tested using the independent sample t-test technique. The results of the study as follows. (1) There is different the Jigsaw type cooperative learning model and NHT model on the improvement of students' teamwork in Social Studies teaching with $t$ score $=0,004<0,05$. The mean gain score of the teamwork of the students using the Jigsaw type cooperative learning model is higher than that of using the NHT model (0,73 > 0,62). (2) There is different of the Jigsaw type cooperative learning model and NHT model on the improvement of students' responsibility in Social Studies teaching with $t$ score $=0,000<0,05$. The mean gain score of responsibility of the students using the Jigsaw type cooperative learning model is higher than that of using the NHT model (0,87 $>0,57)$. So, the Jigsaw type cooperative learning model is more effective in increasing the students' teamwork and responsibility.

Copyright $\left.{ }^{(}\right) 2018$ Rizeki Sugestiningsih dan Ajat Sudrajat.All Right Reserved

\section{PENDAHULUAN}

Undang-Undang Nomor 20 tahun 2003 tentang Sistem Pendidikan Nasional Pasal 3 menyatakan bahwa pendidikan nasional tidak hanya berfungsi memberikan pengetahuan yang dapat mencerdaskan siswa, tetapi juga membentuk karakter siswa. Pendidikan ideal mengarahkan pembentukan kecerdasan, karakter, dan jasmani siswa demi meraih kesempurnaan hidup (Dewantara, 2004). Pengembangan karakter siswa menjadi bagian terpenting untuk dikembangkan dalam dunia pendidikan. Hal ini karena karakter dapat mengarahkan pada pembentukan masyarakat yang berkualitas dan unggul. 
Karakter tersebut mengarahkan sikap dan perilaku masyarakat untuk dapat menjalani kehidupan berbangsa. Selain itu, karakter juga dapat menentukan arah kemajuan dan kemunduran dari kondisi suatu bangsa.

Kenyataan yang terjadi pada saat ini, masyarakat Indonesia justru mengalami gejala kerusakan moral dan karakter bangsa. Kerusakan karakter yang marak terjadi pada masyarakat seperti: korupsi, kejahatan, kekerasan, menurunnya rasa tanggung jawab, dan masyarakat semakin individualistis. Kondisi serupa juga menimpa pada anak-anak dalam dunia pendidikan. Kasus tersebut disebabkan oleh salah satunya pendidikan lebih menekankan pada kognitif-intelektualistik dan mengabaikan aspek afektif siswa. Oleh karena itu, pendidikan perlu mengalami perubahan dan perbaikan melalui pendidikan karakter.

Pendidikan karakter sebagai cara efektif untuk menanamkan kembali nilai-nilai kebaikan dan mengatasi kerusakan karakter siswa. Pendidikan karakter memiliki nilainilai yang perlu dimiliki siswa diantaranya kerja sama dan tanggung jawab. Kerja sama dan tanggung jawab penting dikembangkan dan dimiliki siswa di era globalisasi. Kedua karakter tersebut sangat diperlukan oleh siswa agar berhasil dalam persaingan di dunia kerja, menjalani kehidupan di masyarakat, dan berperan aktif dalam menghadapi tantangan masa depan.
Kerja sama atau gotong royong merupakan sikap dan perilaku siswa yang saling bekerja bersama untuk menyelesaikan tugas dan meraih tujuan bersama. Esensi penting dari kerja sama siswa dikemukakan Lie (2008, hal. 31) bahwa manusia sejatinya dilahirkan sebagai makhluk sosial yang membutuhkan kerja sama dan interaksi dengan orang lain untuk memenuhi kebutuhan hidupnya. Siswa yang berkarakter kerja sama ditunjukkan dengan anggota kelompok dapat saling berbagi tugas, menghargai perbedaan, menyampaikan pendapat, dan mencapai kesepakatan bersama. Siswa timbul kesadaran untuk membantu kesulitan belajar yang dialami orang lain, memastikan anggota kelompok memahami materi belajar, dan menyelesaikan tugas dengan tepat waktu.

Karakter lain yang penting pula dimiliki oleh siswa adalah tanggung jawab. Tanggung jawab siswa sebagai sikap dan perilaku untuk menjalankan tugas dan kewajiban siswa dalam kehidupan. Esensi dari tanggung jawab adalah mengarahkan siswa berperan penting dalam kehidupan dan lebih tangguh dalam mengatasi permasalahan yang dialaminya. Siswa yang bertanggung jawab digambarkan dengan melakukan tugas dengan sebaik-baiknya dan sepenuh hati. Siswa mampu mengembalikan barang yang dipinjam dari orang lain, dan menepati janji yang diucapkan. Siswa yang 
bertanggung jawab dapat menerima resiko, tidak menyalahkan orang lain, dan meminta maaf atas kesalahan yang dilakukan dirinya.

Oleh karena itu, kerja sama dan tanggung jawab siswa sangat penting dikembangkan dalam lingkungan keluarga, masyarakat, dan sekolah.

Sekolah dapat melakukan integrasi pendidikan karakter pada semua mata pelajaran dengan memuatkan pengetahuan tentang kebaikan, tindakan kebaikan, dan perasaan kebaikan. Salah satu mata pelajaran yang dapat diintegrasikan dengan nilai-nilai karakter siswa adalah Ilmu Pengetahuan Sosial (IPS). IPS merupakan mata pelajaran pada tingkatan sekolah dasar dan menengah yang mengembangkan aspek pengetahuan, keterampilan, sikap, dan nilai karakter siswa (Sapriya, 2009).

Pembelajaran IPS berusaha mengembangkan sikap dan perilaku siswa yang berdimensi intelektual, personal, sosiokultural, dan spiritual. Adapun tujuan pembelajaran IPS sejalan dengan pendidikan karakter yakni membekali siswa menjadi warga negara Indonesia yang baik dengan berkarakter demokratis, bertanggung jawab, dan cinta perdamaian.

Pencapaian tujuan IPS tersebut bukan persoalan yang mudah. Pengembangan karakter khususnya kerja sama dan tanggung jawab siswa belum optimal dalam pembelajaran IPS. Trianto (2009, hal. 55) menjelaskan bahwa masalah yang terjadi dalam pembelajaran lebih bersifat kompetitif dan individualistis pada masa sekarang di Indonesia. Suryadi (2014, hal. 98) juga berpendapat bahwa pembelajaran belum mampu menghasilkan warga negara yang bertanggung jawab. Hal ini nampak dari pembelajaran belum mampu mengendalikan kebebasan seseorang tanpa batas, sehingga sikap dan perilakunya merugikan kehidupan bersama.

Pembelajaran IPS yang berlangsung di kelas mengalami beberapa masalah. Supardi (2011, hal. 216-217) menjelaskan bahwa pelaksanaan kurikulum SMP untuk IPS belum menekankan pada pendekatan interdisipliner. Pembelajaran IPS masih dominan pada aspek kognitif saja, guru memiliki motivasi dan inovasi mengajar yang rendah. Kondisi tersebut menyebabkan pembelajaran terasa monoton, kurang bermakna, bahkan terkesan pengetahuan hafalan. Guru seharusnya senantiasa mengembangkan kemampuan mengajarnya sehingga pembelajaran IPS lebih menarik dan bermakna.

Persoalan pembelajaran IPS juga dikemukakan oleh Solihatin \& Raharjo (2009, hal. 3) bahwa sebagian besar guru IPS masih menggunakan model pembelajaran konvensional. Pusat pembelajaran terletak pada guru sedangkan siswa dijadikan objek. Hal ini menyebabkan tujuan IPS sulit dicapai dan kurang mengembangkan potensi siswa. Oleh karena itu, guru dapat 
menggunakan model pembelajaran kooperatif yang inovatif untuk mengembangkan karakter siswa dalam pembelajaran IPS.

Pardjono (2014, hal. 457) berpendapat bahwa model pembelajaran kooperatif dapat digunakan sebagai model penyampaian nilai karakter siswa yang efektif. Model pembelajaran kooperatif merupakan pembelajaran yang melibatkan siswa dalam kelompok kecil saling bekerja bersama untuk memahami materi dan menyelesaikan tugas. Setiap siswa memiliki tanggung jawab atas tugas yang dilaksanakan dalam kelompok. Model pembelajaran kooperatif memiliki beberapa tipe yang dapat dipilih dalam pembelajaran IPS seperti: Jigsaw dan Numbered Heads Together.

Model pembelajaran kooperatif tipe Jigsaw merupakan pembelajaran yang melibatkan siswa dalam tim asal dan tim ahli. Siswa dalam tim dapat bekerja sama untuk mempelajari sub topik yang berbeda dan bertanggung jawab dalam mengajarkan kepada anggota kelompok. Model pembelajaran kooperatif tipe Numbered Heads Together (NHT) adalah pembelajaran yang membagi siswa dalam kelompok kecil dengan penomoran. Setiap siswa dalam kelompok dapat saling bekerja sama untuk mengerjakan tugas, dan memastikan pemahaman materi IPS dari setiap anggota kelompok.
Kedua tipe dalam model pembelajaran kooperatif lebih menonjolkan pada pengembangan kerja sama dan tanggung jawab siswa dalam pembelajaran IPS. Hal ini didukung dengan pendapat Lickona (2013, hal. 286) dalam bukunya "Educating for Character" bahwa model pembelajaran kooperatif tipe Jigsaw dan NHT mampu menanamkan karakter khususnya kerja sama dan tanggung jawab sekaligus meningkatkan keberhasilan belajar siswa. Oleh karena itu, guru perlu menggunakan model pembelajaran kooperatif tipe Jigsaw dan NHT untuk mengembangkan kerja sama dan tanggung jawab siswa dalam pembelajaran IPS di sekolah.

Salah satu sekolah yang menjunjung tinggi penanaman karakter siswa di Kabupaten Sleman Yogyakarta adalah SMP Negeri 2 Depok Sleman. Sekolah tersebut dipilih karena termasuk sekolah favorit dalam kategori sedang dilihat dari pencapaian nilai ujian nasional. Berdasarkan uraian di atas, maka peneliti tertarik untuk melakukan penelitian dengan judul "Perbedaan Model Pembelajaran Kooperatif tipe Jigsaw dan NHT untuk Peningkatan Karakter dalam Pembelajaran IPS di SMP Negeri 2 Depok Sleman".

\section{METODE}

Jenis penelitian ini merupakan penelitian eksperimen semu (quasi experiment research) dengan alasan tidak mungkin semua variabel yang muncul ketika 
kondisi eksperimen dapat dikontrol secara ketat oleh peneliti. Desain penelitian ini menggunakan pre-test post-test nonequivalent group design (Ary, Jacobsen, Sorensen, \&Walker, 2012, hal. 339). Penelitian ini melibatkan kelas eksperimen 1 dengan perlakuan model pembelajaran kooperatif tipe Jigsaw dan kelas eksperimen 2 dengan perlakuan model pembelajaran kooperatif tipe NHT. Kedua kelas eksperimen memiliki karakteristik yang relatif sama. Kedua kelas tersebut dibagikan kuesioner kerja sama dan tanggung jawab siswa. Hasil tersebut dilakukan untuk mengetahui perbedaan model pembelajaran kooperatif tipe Jigsaw dan NHT untuk peningkatan karakter dalam pembelajaran IPS. Penelitian ini dilaksanakan di SMP Negeri 2 Depok Sleman yang beralamat di Jalan Dahlia, Perumnas Condong Catur, Depok, Sleman, Yogyakarta. Waktu penelitian dilaksanakan pada bulan Agustus 2015-Maret 2016 pada siswa kelas VIII semester 2 tahun ajaran 2015/2016.

Pengujian hipotesis menggunakan analisis statistik independent sample t-test terhadap gain score (selisih dari hasil pretest dan post-test) untuk menguji hipotesis penelitian. Pengambilan keputusan pada uji$\mathrm{t}$ berdasarkan pada signifikansi $>0,05$ maka H0 diterima berarti tidak terdapat perbedaan model pembelajaran kooperatif tipe Jigsaw dan NHT untuk peningkatan kerja sama dan tanggung jawab siswa dalam pembelajaran
IPS di SMP Negeri 2 Depok Sleman. Apabila nilai signifikansi $<0,05$ maka $\mathrm{H} 0$ ditolak artinya terdapat perbedaan model pembelajaran kooperatif tipe Jigsaw dan NHT untuk peningkatan kerja sama dan tanggung jawab siswa dalam pembelajaran IPS di SMP Negeri 2 Depok Sleman.

\section{HASIL DAN PEMBAHASAN}

Permasalahan yang muncul dalam pembelajaran IPS di sekolah yakni kerja sama dan tanggung jawab siswa belum berkembang secara optimal. Salah satu faktor yang mempengaruhi masalah tersebut adalah guru masih menggunakan model pembelajaran konvensional dalam pembelajaran IPS. Salah satu model pembelajaran inovatif yang dapat meningkatkan kerja sama dan tanggung jawab siswa adalah model pembelajaran kooperatif. Model pembelajaran kooperatif memiliki beberapa tipe yang dapat dipilih untuk pengembangan karakter siswa diantaranya: tipe Jigsaw dan NHT. Berangkat dari hal tersebut, maka dilakukan penelitian dalam bentuk kuasi eksperimen.

Penelitian ini dilakukan pada kelas eksperimen 1 menggunakan model pembelajaran kooperatif tipe Jigsaw dan kelas eksperimen 2 menggunakan model pembelajaran kooperatif tipe $N H T$. Kedua kelas tersebut memiliki kerja sama dan tanggung jawab siswa yang relatif sama. Penelitian ini bertujuan untuk mengetahui 
dan membuktikan hasil penelitian sebagai berikut.

\section{Data Kerja Sama Siswa}

Data hasil kerja sama siswa dianalisis menggunakan statistik deskriptif. Data hasil kerja sama siswa yang dideskripsikan terdiri dari data hasil kuesioner sebelum (pre-test) dan kuesioner sesudah (post-test) diberikan perlakuan dengan model pembelajaran kooperatif tipe Jigsaw dan NHT. Hasil kuesioner kerja sama siswa dapat dilihat pada tabel di bawah ini.

Tabel 1. Statistik Deskriptif Kerja Sama Siswa

\begin{tabular}{|c|c|c|c|c|}
\hline \multirow{2}{*}{$\begin{array}{l}\text { Besaran } \\
\text { Statistik }\end{array}$} & \multicolumn{2}{|c|}{$\begin{array}{c}\text { Model } \\
\text { Kooperatif } \\
\text { tipe Jigsaw }\end{array}$} & \multicolumn{2}{|c|}{$\begin{array}{c}\text { Model } \\
\text { Kooperatif } \\
\text { tipe } N H T\end{array}$} \\
\hline & $\begin{array}{l}\text { Pre } \\
\text { test }\end{array}$ & $\begin{array}{c}\text { Post } \\
\text { test }\end{array}$ & $\begin{array}{l}\text { Pre } \\
\text { test }\end{array}$ & $\begin{array}{c}\text { Post } \\
\text { test }\end{array}$ \\
\hline $\mathrm{N}$ & 31 & 31 & 31 & 31 \\
\hline $\begin{array}{l}\text { Rerata } \\
\text { Skor }\end{array}$ & 2,13 & 2,86 & 2,10 & 2,71 \\
\hline Median & 2,16 & 2,92 & 2,12 & 2,72 \\
\hline $\begin{array}{l}\text { Standar } \\
\text { Deviasi }\end{array}$ & 0,24 & 0,31 & 0,23 & 0,23 \\
\hline Varian & 0,06 & 0,10 & 0,06 & 0,06 \\
\hline Minimal & 1,68 & 2,12 & 1,64 & 2,16 \\
\hline Maksimal & 2,56 & 3,40 & 2,48 & 3,12 \\
\hline Gain score & \multicolumn{2}{|c|}{0,73} & \multicolumn{2}{|c|}{0,62} \\
\hline $\begin{array}{l}\text { Persentase } \\
\text { gain score }\end{array}$ & \multicolumn{2}{|c|}{34,36} & \multicolumn{2}{|c|}{29,32} \\
\hline
\end{tabular}

Sumber: data diolah peneliti, 2018

Tabel di atas menunjukkan rerata skor post-test kerja sama siswa pada kedua kelas eksperimen lebih tinggi dibandingkan dengan rerata skor pre-test kerja sama siswa pada kedua kelas eksperimen. Rerata posttest kerja sama siswa pada kelas eksperimen yang menggunakan model pembelajaran tipe Jigsaw $(2,86)$ dan NHT $(2,71)$. Sedangkan, rerata skor pre-test kerja sama siswa pada kelas eksperimen yang menggunakan model pembelajaran tipe Jigsaw $(2,13)$ dan $N H T$ $(2,10)$.

Berdasarkan rerata gain score kerja sama siswa tertinggi adalah kelas eksperimen yang menggunakan model pembelajaran kooperatif tipe Jigsaw sebesar 0,73 dengan persentase $34,36 \%$. Rerata gain score kerja sama siswa terendah adalah kelas eksperimen yang menggunakan model pembelajaran kooperatif tipe $N H T$ sebesar 0,62 dengan 29,32\%. Simpulan dari penjelasan tersebut adalah rerata gain score kerja sama siswa yang menggunakan model pembelajaran kooperatif tipe Jigsaw lebih tinggi daripada dengan menggunakan NHT $(0,73>0,62)$.

Skor kuesioner kerja sama siswa dapat dikategorikan dalam bentuk distribusi frekuensi skor kerja sama siswa menunjukkan bahwa hasil post-test kerja sama siswa pada kedua kelas eksperimen terdistribusi frekuensi lebih tinggi dibandingkan hasil pre-test kerja sama siswa pada kedua kelas eksperimen. Berdasarkan hasil post-test kerja sama siswa menunjukkan sebagian besar orang pada kelas eksperimen yang menggunakan model pembelajaran kooperatif tipe Jigsaw dalam kategori baik sebanyak 24 orang $(77,4 \%)$, dan sangat baik sebanyak 2 orang $(6,5 \%)$. Hasil post-test kerja sama siswa yang menggunakan model pembelajaran kooperatif tipe NHT didominasi oleh kategori baik sebanyak 26 orang $(83,9 \%)$. 
Kedua kelas eksperimen dari hasil post-test kerja sama siswa memiliki frekuensi yang sama dalam kategori cukup sebanyak 5 orang $(16,1 \%)$.

Skor pre-test kerja sama siswa pada kedua kelas eksperimen menunjukkan sebagian besar distribusi frekuensi termasuk dalam kategori cukup dengan jumlah yang sama yakni 27 orang $(87,1 \%)$. Skor pre-test kerja sama siswa yang menggunakan model pembelajaran kooperatif tipe Jigsaw dengan kategori kurang sebanyak 3 orang $(9,7 \%)$, dan baik sebanyak 1 orang $(3,2 \%)$. Skor pretest kerja sama siswa yang menggunakan model pembelajaran kooperatif tipe NHT yang termasuk kategori kurang sebanyak 4 orang $(12,9 \%)$.

\section{Data Tanggung Jawab Siswa}

Deskripsi data hasil tanggung jawab siswa terdiri dari data kuesioner sebelum (pre-test) dan kuesioner sesudah (post-test) diberikan perlakuan dengan model kooperatif tipe Jigsaw dan NHT pada kedua kelas eksperimen. Data hasil kuesioner tanggung jawab siswa yang diperoleh dapat dilihat pada tabel di bawah ini.

Tabel 2. Statistik Deskriptif Tanggung Jawab Siswa

\begin{tabular}{ccccc}
\hline Deskripsi & \multicolumn{2}{c}{$\begin{array}{c}\text { Model } \\
\text { Kooperatif } \\
\text { tipe Jigsaw }\end{array}$} & \multicolumn{2}{c}{$\begin{array}{c}\text { Model } \\
\text { Kooperatif } \\
\text { tipe NHT }\end{array}$} \\
\cline { 2 - 6 } & $\begin{array}{c}\text { Pre } \\
\text { test }\end{array}$ & $\begin{array}{c}\text { Post } \\
\text { test }\end{array}$ & $\begin{array}{c}\text { Pre } \\
\text { test }\end{array}$ & $\begin{array}{c}\text { Post } \\
\text { test }\end{array}$ \\
\hline N & 31 & 31 & 31 & 31 \\
Rerata Skor & 2,17 & 3,04 & 2,14 & 2,71 \\
Median & 2,21 & 3,00 & 2,16 & 2,74 \\
Standar & 0,24 & 0,31 & 0,24 & 0,29 \\
Deviasi & & & & \\
Varian & 0,06 & 0,10 & 0,06 & 0,09
\end{tabular}

\begin{tabular}{lcrcc} 
Minimal & 1,63 & 2,47 & 1,58 & 2,16 \\
Maksimal & 2,53 & 3,58 & 2,53 & 3,32 \\
Gain score & 0,87 & 0,57 \\
Persentase & 40,13 & 26,44 \\
gain score & & & \\
\hline
\end{tabular}

Sumber: data diolah peneliti, 2018

Dari tabel di atas menunjukkan rerata skor post-test tanggung jawab siswa pada kedua kelas eksperimen lebih tinggi dibandingkan dengan rerata skor pre-test tanggung jawab siswa pada kedua kelas eksperimen. Rerata post-test tanggung jawab siswa pada kelas eksperimen yang menggunakan model pembelajaran tipe Jigsaw $(3,04)$ dan NHT $(2,71)$. Sedangkan, rerata skor pre-test tanggung jawab siswa pada kelas eksperimen yang menggunakan model pembelajaran tipe Jigsaw $(2,17)$ dan NHT $(2,14)$.

Berdasarkan hasil rerata gain score tanggung jawab siswa yang tertinggi adalah kelas eksperimen yang menggunakan model pembelajaran kooperatif tipe Jigsaw sebesar 0,87 dengan persentase $40,13 \%$. Rerata gain score tanggung jawab siswa yang terendah adalah kelas eksperimen yang menggunakan model pembelajaran kooperatif tipe $N H T$ sebesar 0,57 dengan 26,44\%. Simpulan dari penjelasan tersebut adalah rerata gain score tanggung jawab siswa yang menggunakan model pembelajaran kooperatif tipe Jigsaw lebih tinggi dibandingkan dengan menggunakan $N H T(0,87>0,57)$.

Skor kuesioner tanggung jawab siswa dapat dikategorikan dalam bentuk distribusi frekuensi skor tanggung jawab siswa dapat 
dilihat bahwa hasil post-test tanggung jawab siswa pada kedua kelas eksperimen terdistribusi frekuensi lebih tinggi dibandingkan hasil pre-test tanggung jawab siswa pada kedua kelas eksperimen. Berdasarkan hasil post-test tanggung jawab siswa menunjukkan sebagian besar orang pada kelas eksperimen yang menggunakan model pembelajaran kooperatif tipe Jigsaw dalam kategori baik sebanyak 21 orang $(67,7 \%)$, sangat baik sebanyak 9 orang $(29,0 \%)$, dan cukup sebanyak 1 orang $(3,2 \%)$. Hasil post-test tanggung jawab siswa yang menggunakan model pembelajaran kooperatif tipe NHT didominasi oleh kategori baik sebanyak 22 orang $(71,0 \%)$, cukup sebanyak 8 orang $(25,8 \%)$, dan sangat baik sebanyak 1 orang $(3,2 \%)$.

Hasil pre-test tanggung jawab siswa pada kedua kelas eksperimen menunjukkan sebagian besar distribusi frekuensi termasuk dalam kategori cukup dengan jumlah yang sama yakni 27 orang $(87,1 \%)$. Hasil pre-test tanggung jawab siswa yang menggunakan model pembelajaran kooperatif tipe Jigsaw dengan kategori kurang dan baik memiliki frekuensi yang sama sebanyak 2 orang $(6,5 \%)$. Hasil pre-test tanggung siswa jawab yang menggunakan model pembelajaran kooperatif tipe NHT yang termasuk kategori kurang sebanyak 3 orang $(9,7 \%)$, dan baik sebanyak 1 orang $(3,2 \%)$.

\section{Hipotesis 1}

Hipotesis Alternatif $\left(\mathrm{H}_{\mathrm{a}}\right)$ : Terdapat perbedaan pengaruh yang signifikan antara model pembelajaran kooperatif tipe Jigsaw dan Numbered Heads Together untuk peningkatan kerja sama siswa dalam pembelajaran IPS di SMP Negeri 2 Depok Sleman.

Hipotesis Nol (Ho): Tidak terdapat perbedaan pengaruh yang signifikan antara model pembelajaran kooperatif tipe Jigsaw dan Numbered Heads Together untuk peningkatan kerja sama siswa dalam pembelajaran IPS di SMP Negeri 2 Depok Sleman.

Keputusan pada uji hipotesis penelitian diperoleh dari hasil analisis dengan menggunakan uji-t dapat dilihat bahwa kerja sama siswa dengan diasumsikan kedua varian model pembelajaran kooperatif tipe Jigsaw dan NHT sama maka diperoleh signifikasi (2-tailed) sebesar 0,004 0,05. Hasil tersebut artinya bahwa hipotesis nol (Ho) ditolak sehingga hipotesis alternatif (Ha) diterima. Hasil tersebut membuktikan bahwa terdapat perbedaan pengaruh yang signifikan antara model pembelajaran kooperatif tipe Jigsaw dan Numbered Heads Together untuk peningkatan kerja sama siswa dalam pembelajaran IPS di SMP Negeri 2 Depok Sleman.

Berdasarkan hasil uji-t terdapat perbedaan pengaruh yang signifikan antara model pembelajaran kooperatif tipe Jigsaw 
dan Numbered Heads Together untuk peningkatan kerja sama siswa $(0,004<$ 0,05). Hal ini juga sesuai dengan hasil pada tabel 2 menunjukkan bahwa ada peningkatan gain score kerja sama siswa dengan model pembelajaran kooperatif tipe Jigsaw lebih tinggi dibandingkan dengan peningkatan kerja sama siswa yang menggunakan model pembelajaran kooperatif tipe $N H T(0,73>$ 0,62). Peningkatan kerja sama siswa terjadi dikarenakan pada model pembelajaran kooperatif tipe Jigsaw memiliki beberapa kelebihan dibandingkan dengan model pembelajaran kooperatif tipe $N H T$.

Kelebihan dalam menggunakan model pembelajaran kooperatif tipe Jigsaw meliputi: menciptakan hubungan ketergantungan antar siswa saat pembelajaran, siswa dapat bekerja sama untuk menyelesaikan tugas kelompok, partisipasi siswa dalam berpendapat dan bertanya meningkat, melatih siswa untuk bertanggung jawab dalam mengajarkan materi kepada anggota kelompok, penguasaan materi siswa dapat merata dalam waktu singkat, dan meningkatkan prestasi belajar siswa.

Tran \& Lewis (2012) menjelaskan bahwa siswa yang diberikan perlakuan dengan model pembelajaran kooperatif tipe Jigsaw lebih mampu bekerjasama dan meningkatkan prestasi belajar. Selain itu pula, siswa yang diberikan model pembelajaran kooperatif tipe Jigsaw dapat menghargai hasil kerja orang lain, mendapatkan bantuan, saling berbagi informasi, dan mengajarkan materi kepada orang lain.

Lie (2004, hal. 69) berpendapat bahwa model pembelajaran kooperatif tipe Jigsaw berusaha menggabungkan kegiatan membaca, menulis, mendengarkan, dan berbicara. Model pembelajaran kooperatif tipe Jigsaw sangat tepat digunakan pada berbagai mata pelajaran dengan tingkatan kelas yang berbeda. Siswa yang diberikan perlakuan menggunakan model pembelajaran kooperatif tipe Jigsaw dapat bekerja dengan anggota kelompok dalam situasi kerja sama, memiliki kesempatan mengolah informasi, meningkatkan keterampilan berkomunikasi, dan pembelajaran menjadi lebih bermakna.

Lickona (2013, hal. 286) menjelaskan bahwa metode Jigsaw dapat menciptakan kesamaan dalam berpartisipasi dan membangun sikap saling ketergantungan. Hal ini dilakukan dengan cara semua siswa didorong untuk berperan aktif dan penting di dalam dua kelompok yakni kelompok asal dan kelompok ahli. Siswa dalam kelompok ahli saling bekerja sama untuk mempelajari dan berdiskusi sub materi yang menjadi keahliannya. Pada kelompok asal, siswa saling bekerja sama mempelajari sub materi yang terpisah menjadi kesatuan materi yang utuh, saling mendiskusikan materi yang 
berbeda-beda, dan menyelesaikan tugas kelompok.

Menurut Partana (2008, hal. 160) bahwa model pembelajaran kooperatif tipe Jigsaw memuat kegiatan diskusi dan mengarahkan siswa agar dapat mengajarkan materi kepada anggota kelompok. Siswa dapat lebih menghargai pendapat orang lain, berkesempatan dalam menyampaikan pendapat maupun bertanya, dan siswa dapat menguasai seluruh materi yang telah dipelajarinya dalam kelompok. Penggunaan model pembelajaran kooperatif tipe Jigsaw mampu mengembangkan karakter siswa, dan menciptakan suasana belajar yang menyenangkan sehingga pembelajaran menjadi efektif.

\section{Hipotesis 2}

Hipotesis Alternatif (Ha): Terdapat perbedaan pengaruh yang signifikan antara model pembelajaran kooperatif tipe Jigsaw dan Numbered Heads Together untuk peningkatan tanggung jawab siswa dalam pembelajaran IPS di SMP Negeri 2 Depok Sleman.

Hipotesis Nol (Ho): Tidak terdapat perbedaan pengaruh yang signifikan antara model pembelajaran kooperatif tipe Jigsaw dan Numbered Heads Together untuk peningkatan tanggung jawab siswa dalam pembelajaran IPS di SMP Negeri 2 Depok Sleman.

Keputusan pada uji hipotesis penelitian diperoleh dari hasil analisis dengan menggunakan uji-t dapat bahwa tanggung jawab siswa dengan diasumsikan kedua varian model kooperatif tipe Jigsaw dan NHT sama maka diperoleh signifikasi (2-tailed) sebesar $0,000<0,05$. Hasil tersebut artinya bahwa hipotesis nol (Ho) ditolak sehingga hipotesis alternatif ( $\mathrm{Ha})$ diterima. Hasil tersebut membuktikan bahwa terdapat perbedaan pengaruh yang signifikan antara model pembelajaran kooperatif tipe Jigsaw dan Numbered Heads Together untuk peningkatan tanggung jawab siswa dalam pembelajaran IPS di SMP Negeri 2 Depok Sleman.

Terdapat perbedaan pengaruh yang signifikan antara model pembelajaran kooperatif tipe Jigsaw dan Numbered Heads Together untuk peningkatan tanggung jawab siswa $(0,000<0,05)$. Tabel 4 menunjukkan ada peningkatan gain score tanggung jawab siswa dengan model pembelajaran kooperatif tipe Jigsaw lebih tinggi dibandingkan dengan peningkatan tanggung jawab siswa yang menggunakan model pembelajaran kooperatif tipe $N H T(0,87>$ $0,57)$.

Model pembelajaran kooperatif tipe Jigsaw dapat meningkatkan tanggung jawab siswa dikarenakan siswa pada kelompok ahli dapat bertanggung jawab untuk mempelajari dan mengajarkan materi tersebut kepada anggota kelompok. Hal ini sesuai dengan pendapat dari Carpenter (2006) bahwa model pembelajaran kooperatif tipe Jigsaw 
melibatkan siswa untuk saling bekerja sama dan bertanggung jawab dalam kelompok. Tanggung jawab siswa dalam kelompok yakni mempelajari materi tertentu pada kesatuan materi utuh. Anggota kelompok juga bertanggung jawab dalam menjelaskan bagian bab yang telah dipelajarinya kepada seluruh anggota kelompok.

Metode Jigsaw mengarahkan setiap siswa bertanggung jawab untuk menguasai salah satu bagian dari materi dan mengajarkan bagian tersebut kepada anggota dalm kelompok (Arends, 2008, hal. 13). Lickona (2013, hal. 286) menjelaskan bahwa metode Jigsaw melibatkan siswa dalam kelompok ahli dan asal. Siswa yang ahli dalam sub materi tertentu dapat bertanggung jawab untuk mengajarkan materi kepada anggota kelompok asal. Setiap siswa dalam kelompok asal termotivasi untuk mendengarkan penjelasan dari para ahli sehingga siswa. Hal ini agar siswa dapat memahami materi dan bertanggung jawab dalam ujian individu yang akan diberikan dengan mencakup semua sub topik.

Model pembelajaran kooperatif tipe Jigsaw mampu meningkatkan kualitas pembelajaran yang berdampak pada perubahan sikap dan perilaku siswa yang terlihat dari meningkatnya rasa tanggung jawab. Mulyani berpendapat bahwa penggunaan model kooperatif tipe Jigsaw dapat meningkatkan kualitas pembelajaran pendidikan kewarganegaraan pada standar kompetensi memahami pelaksanaan demokrasi bagi siswa kelas VIII H semester 2 SMP Negeri 21 Semarang Tahun Ajaran 2010/2011.

\section{SIMPULAN}

Berdasarkan hasil penelitian yang telah dilaksanakan dapat disimpulkan sebagai berikut. (1) terdapat perbedaan pengaruh yang signifikan antara model pembelajaran kooperatif tipe Jigsaw dan Numbered Heads Together untuk peningkatan kerja sama siswa dalam pembelajaran IPS di SMP Negeri 2 Depok Sleman. Hal ini dibuktikan dari hasil uji-t untuk kerja sama siswa yang memiliki nilai signifikasi $0,004<0,05$. Hasil gain score menunjukkan ada peningkatan kerja sama siswa yang menggunakan model pembelajaran kooperatif tipe Jigsaw lebih tinggi dibandingkan dengan NHT sebesar $0,73>0,62$. (2) Terdapat perbedaan pengaruh yang signifikan antara model pembelajaran kooperatif tipe Jigsaw dan Numbered Heads Together untuk peningkatan tanggung jawab siswa dalam pembelajaran IPS di SMP Negeri 2 Depok Sleman. Hal ini dibuktikan dari hasil uji-t untuk tanggung jawab siswa yang memiliki nilai signifikasi $0,000<0,05$. Hasil gain score menunjukkan ada peningkatan tanggung jawab siswa dengan model pembelajaran kooperatif tipe Jigsaw lebih tinggi dibandingkan dengan NHT sebesar $0,87>0,57$. 


\section{DAFTAR PUSTAKA}

Arends, R. I. (2008). Learning to teach belajar untuk mengajar. (Terjemahan Helly Prajitno \& Sri Mulyantini Soetjipto). New York: McGraw Hill Companies. (buku asli diterbitkan 2007).

Ary, D., Jacobs, L. C., Sorensen, C., \& Walker, D. A. (2012). Introduction to research in education. Belmont: Wadsworth.

Carpenter, J. M. (2006). Effective teaching methods for large classes. Jurnal of Family \& Consumer Sciences Education (Vol. 24, 2).

Dewantara, K. H. (2004). Karya ki hadjar dewantara bagian pertama pendidikan: Cetakan Ketiga. Yogyakarta: Majelis Luhur Persatuan Taman Siswa.

Lickona, T. (2013). Educating for character: mendidik untuk membentuk karakter bagaimana sekolah dapat memberikan pendidikan tentang sikap hormat dan bertanggung jawab. (Terjemahan Juma Abdu Wamaungo). New York: Corwin Press Inc. (buku asli diterbitkan 2002).

Lie, A. (2004). Cooperative learning: mempraktikkan cooperatif learning di ruang-ruang kelas. Jakarta: PT. Gramedia Widiasarana Indonesia.

Pardjono. (2014). Pengembangan karakter siswa SMK melaui mata pelajaran: kajian kasus dalam mata pelajaran gambar teknik mesin. Proceeding memantapkan pendidikan karakter untuk melahirkan insan bermoral, humanis, dan profesional. Yogyakarta, 453-467.

Partana, C. F. (2008). Kajian efektivitas penerapan metode pembelajaran kooperatif tipe jigsaw dan stad pada mata pelajaran IPA aspek kimia di
SMP 2 Mlati Sleman. Jurnal Ilmiah Pendidikan: Cakrawala Pendidikan, No. 2, 152-163.

Republik Indonesia. (2003). Undangundang RI nomor 20, tahun 2003, tentang sistem pendidikan nasional.

Sapriya. (2009). Pendidikan IPS konsep dan pembelajaran. Bandung: PT Remaja Rosdakarya.

Solihatin, E \& Raharjo. (2009). Cooperative learning: analisis model pembelajaran IPS. Jakarta: Bumi Aksara.

Supardi. (2011). Dasar-dasar ilmu sosial. Yogyakarta: Penerbit Ombak.

Suryadi, A. (2014). Pendidikan Indonesia menuju 2025 outlook: permasalahan, tantangan \& alternatif kebijakan. Bandung: PT. Remaja Rosdakarya.

Tran, V. D. \& Lewis, R. (2012). The effects of jigsaw learning on students attitudes in a vietnamese higher education classroom. International Jurnal of Higher Education Vol. 1, No. 2, 9-20).

Trianto. (2009). Mendesain model pembelajaran inovatif-progresif: konsep, landasan, dan implementasinya pada kurikulum tingkat satuan pendidikan (KTSP). Jakarta: Kencana Prenada Media Group. 